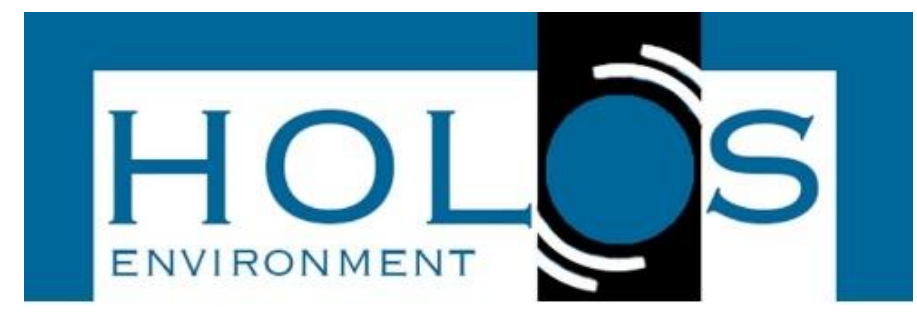

\title{
EFFECTS OF SEWAGE SLUDGE ON THE GROWTH OF Coffea Arabica SEEDLINGS AND CELL CYCLE OF Allium cepa
}

\section{EFEITOS DE LODO DE ESGOTO NO CRESCIMENTO DE MUDAS DE Coffea arabica E NO CICLO CELULAR DE Allium cepa}

\author{
Glaucia de Mello Cunha Gouvea ${ }^{1}$, Victor Ventura de Souza², Glaucio de Mello \\ Cunha ${ }^{2}$, Tatiana da Silva Souza ${ }^{1,2}$
}

Artigo recebido em: 24/10/2019 e aceito para publicação em: 21/11/2019.

DOI: http://dx.doi.org/10.14295/holos.v19i4.12357

\begin{abstract}
Sewage sludge can contain toxic compounds and pathogens therefore it agronomic use must occur in a safer way to the population and environment. The objective of this study was to investigate the effects of substrates containing different proportions of sanitized sewage sludge in the growth of Coffea Arabica seedlings and to verify the cytogenotoxic potential of these substrates using the analysis of Allium cepa cell cycle. The substrate with the lowest proportion of sewage sludge (15\%) was the one that obtained the greatest growth performance and did not present cytogenotoxic activity. Substrates with the highest concentrations of sanitized sewage sludge (30, 45 e $60 \%)$ were toxics. For coffee seedlings, all the growth variables decreased and the significant induction of aberrant meristematic cells in A. cepa was observed. However, the sewage toxicity was not related to the presence of metals, whose levels were within the maximum limits allowed by the Brazilian legislation, indicating that these biological tests are essential for the determination of the quality of sewages before their agricultural use.
\end{abstract}

Keywords: Biosolid. Initial plant growth. Phytotoxicity. Genotoxicity.

Resumo: O lodo de esgoto pode conter substâncias tóxicas e patógenos, portanto seu uso agronômico deve ocorrer de modo seguro para a população e meio ambiente. O objetivo desse estudo foi investigar os efeitos de substratos contendo diferentes proporções de lodo de esgoto higienizado no crescimento inicial de mudas de Coffea Arabica e verificar o potencial citogenotóxico desses substratos mediante a análise do ciclo celular de Allium cepa. O substrato com a menor proporção de lodo de esgoto (15\%) foi o que proporcionou as maiores performances de crescimento e não apresentou atividade citogenotóxica. Substratos com as maiores concentrações de lodo (30, 45 e $60 \%$ ) foram tóxicos. Para as mudas de café, todas as variáveis de crescimento diminuíram e a indução significativa de células aberrantes no meristema de A. cepa foi observada. Entretanto, a toxicidade do lodo não foi relacionada com as concentrações de metais, cujos níveis não ultrapassaram os limites máximos estabelecidos pela legislação brasileira, indicando que testes biológicos são essenciais para a determinação da qualidade de lodos antes de sua disposição agrícola.

Palavras-chave: Bissólido. Crescimento inicial de plantas. Fitotoxicidade. Genotoxicidade.

1 Programa de Pós-Graduação em Genética e Melhoramento, Centro de Ciências Agrárias e Engenharias, Universidade Federal do Espírito Santo (UFES), Alegre, Espírito Santo, Brasil. E-mails: (glauciagouvea@yahoo.com.br, tatianas.souza@hotmail.com)

2 Departamento de Biologia, Centro de Ciências Exatas, Naturais e da Saúde, Universidade Federal do Espírito Santo (UFES), Alegre, Espírito Santo, Brasil. E-mails: (victorventurabh@yahoo.com.br, glaucioml@yahoo.com.br) 


\section{INTRODUCTION}

Brazil is the biggest producer and exporter of coffee and second biggest consumer of the product in the world (INCAPER, 2010). As the success of the coffee production depends primarily on the quality of the seedlings, coffee growers have been looking for alternatives to reduce the production costs, especially fertilization costs. Studies on the feasibility of using sewage sludge as substrate of seedlings of economic interest have been conducted (CUNHA et al., 2006; CALDEIRA et al., 2013), due to its high content of organic matter and nutrients, replacing conventional organic fertilizers (BRASIL, 2006). However, few studies have focused on the use of sewage sludge as alternative substrate for the qualitative and quantitative growth of coffee seedlings (COSTA et al., 1999; ALVES et al., 2016), which can be evaluated by the morphological analysis of the aerial part and root system (TATAGIBA et al., 2010).

Determining the ideal proportion of sewage sludge used in the substrates is necessary, since this parameter is directly related to the availability of the nutrients present in the residue and with its toxic potential, which can affect the growth of the plants (COSTA et al., 1999; ALVES et al., 2016). The toxicity of the sewage sludge can be attested when it does not meet the criteria established by the environmental protection agencies, such as acceptable levels of pathogens, toxic metals and persistent organic compounds (BRASIL, 2006). However, it is very difficult to assess the toxicity of the sludge only based on the chemical determination of priority pollutants. Thus, bioassays are recommended, in addition to its chemical characterization, since they predict the direct action of complex samples on living organisms by detecting effects from the interactions between the chemicals present (BONOMO et al., 2016; MARTINS et al., 2016a).

The analysis of the cell cycle of Allium cepa indicates the presence of environmental contaminants that have as target the DNA and the mitotic machinery, allowing the understanding of the deleterious action of the compounds with cytotoxic, genotoxic and/or mutagenic properties (LEME, MARIN-MORALES, 2009). In the review paper of Martins et al., (2016a), A. cepa was identified as the most used plant species for the investigation of the cytogenotoxic potential of the sewage sludge. In addition to its low cost, the bioassay with onion allows the detection of cytogenotoxins even at low concentrations (LEME, MARIN-MORALES, 2009), besides presenting high correlation 
(82\% of positive responses) with carcinogenicity tests with mammals (RANK, NIELSEN, 1994).

Based on the foregoing, the present study aimed to investigate the effects of substrates containing different proportions of sanitized sewage sludge on the growth of Coffea Arabica seedlings, as well as to verify the cytogenotoxic potential of the substrates using the analysis of the $A$. cepa cell cycle.

\section{MATERIAL AND METHODS}

\subsection{Biological Material}

Seeds of C. arabica (Arabica coffee cultivar IAC 44) were purchased from a plant nursery located in the municipality of Alegre - Espírito Santo. For the genetic toxicity assays, seeds of $A$. cepa were used (baia periforme variety, Isla ${ }^{\circledR}$, batch $n^{\circ}$ 774758).

\subsection{Collection, characteristics and sanitation of the sewage sludge}

Sewage sludge samples were collected in accordance with the Brazilian Association of Technical Standards - ABNT-NBR 10007 (ABNT, 2004) at a Sewage Treat-

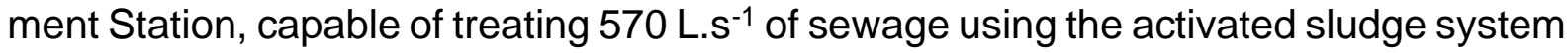
by prolonged aeration (MARQUES et al., 2015). Chemical and microbiological analysis of the sewage sludge was provided by the Sanitation Agency of State of Espírito Santo. These analyses showed that the sewage sludge meets the parameters established by the Resolution no 375 of the National Environment Council (BRASIL, 2006) regarding the concentration of metals and organic pollutants (Supplemental Material). However, the sludge presented thermotolerant coliforms, viable eggs of helminths and Salmonella levels above the allowed (Supplemental Material). Thus, the residue was submitted to a hygienization process that followed the protocol proposed by LIMA et al., (2011). For 30 days, the sludge was maintained on plastic canvas, exposed to the sun and mixed with virgin lime at the proportion of $30 \%$ as a function of the dry weight of the residue. After hygienization, the residue showed pathogens levels acceptable by Brazilian legislation (Supplemental Material). 


\subsection{Substrates containing sanitized sewage sludge}

Five substrates (S1-S5), with six replicates, were prepared according to Bergo et al. (2002) for the growth of coffee seedlings. The substrate S1 was prepared with Horizon B clay soil $(85 \mathrm{~L}$ ) and bovine manure $(15 \mathrm{~L})$, considered traditional by coffee producers since it is source of organic matter and nutrients. For the other substrates, increasing doses of sanitized sewage sludge were used to replace bovine manure: 85 $\mathrm{L}$ soil + $15 \mathrm{~L}$ sewage sludge (substrate $\mathrm{S} 2$ ), $70 \mathrm{~L}$ soil + $30 \mathrm{~L}$ sewage sludge (substrate S3), $55 \mathrm{~L}$ soil $+45 \mathrm{~L}$ sewage sludge (substrate $S 4$ ) and $40 \mathrm{~L}$ soil + $60 \mathrm{~L}$ sewage sludge (substrate S5). Following Bergo et al. (2002), $50 \mathrm{~g} \mathrm{~K} \mathrm{~K}_{2} \mathrm{O}, 150 \mathrm{~g}$ calcareous and $100 \mathrm{~g}$ $\mathrm{P}_{2} \mathrm{O}_{5}$ were added in each substrate.

Samples of the substrates were submitted to chemical analysis where the following parameters were determined: $\mathrm{pH}$ in relation to soil-water 1:2,5; P: extractor Mehlich-1 and colorimetric determination; $\mathrm{K}$ and $\mathrm{Na}$ : extractor Mehlich-1 and determination by flame spectrometry; $\mathrm{Ca}$ and $\mathrm{Mg}$ : extractor $\mathrm{KCl} 1 \mathrm{~mol} / \mathrm{L}$ and determination by atomic absorption spectrometry; $\mathrm{Al}$ : extractor $\mathrm{KCl} 1 \mathrm{~mol} / \mathrm{L}$ and determination by titulometry; $\mathrm{H}+\mathrm{Al}$ : extractor calcium acetate $0.5 \mathrm{~mol} / \mathrm{L} \mathrm{pH} 7.0$ and organic matter: wet carbon oxidation with potassium dichromate in acidic medium $\left(\mathrm{H}_{2} \mathrm{SO}_{4}\right)$ (EMBRAPA, 1997). These analyses were performed in the Laboratory of Chemical Analysis of the Soil Raphael M. Bloise, of the Universidade Federal do Espírito Santo.

\subsection{Seeding, production and analysis of the coffee plants growth}

After being prepared, the substrates were packed in polyethylene bags suitable for the production of coffee seedlings. Sowing and seedling production followed the methodology proposed by Bergo et al., (2002). Three seeds of Arabica coffee were distributed per substrate/replicate at a depth of $2 \mathrm{~cm}$. Later, the seeds were covered by a thin layer of substrate and maintained under cover of jute (Corchorus capsularis) fibre fabric moistened twice a day until the emergency began. After germination, the plants were maintained at $50 \%$ shade condition and the irrigations were performed twice daily until the end of the experiment. At the development stage of "jaguar ear" a thinning was made maintaining one plant per plastic container.

During the seedlings growth, three pulverizations containing macronutrients $(\mathrm{N}$, $\mathrm{Mg}$ and $\mathrm{S}$ ) and micronutrients ( $\mathrm{Fe}, \mathrm{Cu}, \mathrm{Mn}, \mathrm{B}, \mathrm{Zn}$ and $\mathrm{Mo}$ ) were performed by foliar via 
(BERGO et al., 2002). The first application was carried out 150 days after the sowing and the two subsequent applications were performed with an interval of 15 days, that is, at 165 days and 180 days.

After eight months of sowing, the height $(\mathrm{cm})$, stalk diameter $(\mathrm{cm})$, foliar area $\left(\mathrm{cm}^{2}\right)$, dry weight of the aerial part $(\mathrm{g})$ and dry weight of the roots $(\mathrm{g})$ of the plants were measured. The height and the diameter of the stalk were obtained with graduated ruler and pachymeter, respectively. A leaf perforator with a known circular area $\left(0.91 \mathrm{~cm}^{2}\right)$ was used to determine the foliar area. The discs were removed, avoiding sampling the central vein. Posteriorly, these discs were disposed together with the leaves in paper packs to be taken to forced ventilation oven at $60^{\circ} \mathrm{C}$ during 72 hours. Using the dry weight $(\mathrm{g})$ of these discs and the total dry weight $(\mathrm{g})$ of the leaves, the foliar area was calculated (LOPES, MAESTRI, 1973). The dry weight of the aerial part and of the root were quantified by weighing these regions, after drying in the forced ventilation oven, at $70^{\circ} \mathrm{C}$, for a period of, approximately, 72 hours.

The statistical analyses were performed using the computational software Genes (CRUZ, 2006). For each growth variable of the coffee seedlings a variance analysis was made for the regression study of orthogonal polynomials (BANZATTO, KRONKA, 2006). The equation model for each dependent variable was determined from the regression equation of the highest significant degree $(p<0.05)$, where it was possible to establish the relationship between the dose of sanitized sewage sludge with the variables in question.

\subsection{Bioassay with A. cepa}

Seeds of $A$. cepa were germinated (in BOD chamber at $24^{\circ} \mathrm{C}$ ) directly in Petri dishes containing the substrates (S1-S5) and pure sanitized sewage sludge (LE). Distilled water and colchicine $0.025 \%$ were used as negative and positive control, respectively. After reaching approximately $1.5 \mathrm{~cm}$ in length, the radicles were fixed in ethyl alcohol + acetic acid (3:1). For the preparation of the slides, the radicles were hydrolysed in $\mathrm{HCl} 1 \mathrm{~N}$ at $60^{\circ} \mathrm{C}$ for 8 minutes and submitted to Schiff's Reactive, where they remained for two hours in a dark place. The meristematic region of the roots was sectioned on the slide, stained with acetic carmine $2 \%$, covered with coverslips and macerated. The material was analysed under light microscope with magnification of 400x. 5,000 cells were counted per treatment ( 500 cells in 10 slides). The criteria for analysis 
were determined according to LEME and MARIN-MORALES (2009). Cytotoxicity of the substrates was determined by the mitotic index analysis. Aberrant cells, observed in each state of the cell cycle (prophase, metaphase, anaphase and telophase), were grouped into the same category. The frequency of each alteration observed was also individually calculated. Statistical analysis was carried out using the software Bioestat 5.3. The Shapiro-Wilk normality test was used to verify the normality of the samples. As the normality criteria were not met, the Kruskal-Wallis non-parametric test, with posterior Dunn's test $(p<0.05)$ was used.

\section{RESULTS AND DISCUSSION}

\subsection{Chemical characterization of the substrates}

The substrate containing bovine manure presented $\mathrm{pH}$ of 6.9. The substitution of manure by sanitized sewage sludge led to the increase of the $\mathrm{pH}$ of the substrates and reduction of the content of $\mathrm{P}$. Contents of $\mathrm{K}$ and $\mathrm{Mg}$ were higher in the substrate containing bovine manure. Sewage sludge promoted the increase of the concentration of $\mathrm{Ca}$. A reduction of the contents of $\mathrm{Al}$ and $\mathrm{H}+\mathrm{Al}$ was observed, concomitantly with an increase of the $\mathrm{pH}$. The organic matter content increased as a function of the increase of sanitized sewage sludge, being the lowest concentration reported for substrate S1 $(5.0 \mathrm{~g} / \mathrm{Kg})$ and the highest for S5 $(16.69 \mathrm{~g} / \mathrm{Kg})($ Table 1).

Table 1- Chemical analysis of substrates prepared from bovine manure or sanitized sewage sludge

\begin{tabular}{|c|c|c|c|c|c|c|c|c|}
\hline \multirow[t]{2}{*}{ Substrates } & \multirow[t]{2}{*}{$\begin{array}{c}\mathrm{pH} \\
\left(\mathrm{H}_{2} \mathrm{O}\right)\end{array}$} & $\mathbf{P}$ & $\mathrm{K}$ & $\mathrm{Ca}$ & $\mathbf{M g}$ & $\overline{\mathrm{Al}}$ & \multirow[t]{2}{*}{$\begin{array}{c}\mathrm{H}+\mathrm{Al} \\
\left(\mathrm{cmolc} / \mathrm{dm}^{3}\right)\end{array}$} & \multirow[t]{2}{*}{$\underset{(g / K g)}{O M}$} \\
\hline & & \multicolumn{5}{|c|}{$\left(\mathrm{mg} / \mathrm{dm}^{3}\right)$} & & \\
\hline S1 & 6.90 & 37.73 & 270.0 & 3.43 & 1.65 & 0 & 0 & 5.67 \\
\hline S2 & 7.73 & 36.07 & 176.0 & 4.82 & 1.05 & 0 & 0 & 5.0 \\
\hline S3 & 7.99 & 5.94 & 149.0 & 5.31 & 0.96 & 0 & 0 & 9.68 \\
\hline S4 & 7.78 & 20.81 & 190.0 & 6.54 & 1.55 & 0 & 0 & 16.02 \\
\hline S5 & 8.11 & 21.72 & 120.0 & 6.48 & 1.39 & 0 & 0 & 16.69 \\
\hline
\end{tabular}

S1: Substrate containing 15\% bovine manure: S2: Substrate with 15\% sanitized sewage sludge: S3: Substrate with $30 \%$ sanitized sewage sludge. S4: Substrate containing $45 \%$ sanitized sewage sludge. S5: Substrate with $60 \%$ sanitized sewage sludge.

\subsection{Growth of C. arabica plants}

The results regarding the analysis of the growth of coffee seedlings are shown 
in Figure 1. The substrate containing bovine manure promoted growth values similar to those available in the literature for Arabica coffee (SOUZA et al., 2017). Among the substrates with sewage sludge, S2, with the lowest sludge proportion (15\%), obtained better growth performance, but resulted in seedlings of inferior quality than those of the conventional treatment. The increase of the sanitized sewage sludge doses affected negatively the coffee seedlings, due to the reduction of the growth variables. The reduction of the foliar area compromises the photosynthetic process, reflecting in the height and stalk diameter. The stalk diameter measures the survival capacity of the seedling in the field, since it has direct relationship with the average size of the root system. Dry matter is a reflex of the liquid photosynthetic production added to the amount of mineral nutrients absorbed (TATAGIBA et al., 2010). Therefore, in the experimental conditions of this study, seedlings produced in substrates with $45 \%$ and $60 \%$ of sewage sludge would not be able to survive in the field. These data corroborate the results of ALVES et al. (2016), who verified that the use of sewage sludge in tis pure form or at high doses reduced significantly the quality and viability of coffee seedlings.

Sanitation of the sewage sludge is a necessary practice for its agricultural destination, since it aims to reduce the contamination by pathogens and parasites to levels acceptable by the Conama Resolution no 375 (BRASIL, 2006). Disinfection by the addition of virgin lime occurs due to an exothermic reaction that raises the temperature and $\mathrm{pH}$ of the sludge, which makes the medium improper for the survival and development of pathogens (LIMA et al., 2011). But, although essential, sanitation process can elevate the $\mathrm{pH}$ of the substrate at levels above the optimum for the coffee plantation (pH 6.0 to 6.5), which tends to decrease the availability of soil nutrients to the plants (EMBRAPA, 2004). Thus, COSTA et al. (1999) and SILVA (2015) attributed the underdevelopment of coffee seedlings to the high $\mathrm{pH}$ of substrates containing limed sludge. COSTA et al. (1999) verified that with the increase of the lime dose and consequent elevation of $\mathrm{pH}$ (greater than 9), the seedlings of $C$. canephora presented visual symptoms typical of nutritional deficiency and decrease, below the foliar levels considerate adequate, of the contents $\mathrm{P}, \mathrm{K}, \mathrm{Fe}, \mathrm{Zn}, \mathrm{Mn}$ and $\mathrm{Cu}$. In the same way, the results obtained in this study indicated that the alkalinity of the substrates containing sanitized sewage sludge promoted mainly the reduction of the levels of $P$, which is essential for the development of the plants, since it has crucial role in the cell energy transference, respiration and photosynthesis. It is also a structural component of the nucleic acids, 
as well as of many coenzymes, phosphoproteins and phospholipids that constitute the cell membranes. Reduction in the $P$ availability in the beginning of the vegetative cycle may result in development restriction (SCHUMACHER et al., 2003).

The deficiency of $P$ can explain the results obtained for the dry mass of the root. In this condition, there was a significant reduction of this parameter in function of the increment of sewage sludge up to the dose of $30 \%$. From this dose there was an inversion, represented by a slight increase of the root dry mass in the substrate containing $45 \%$ of the sewage sludge and a more pronounced increase in the substrate with $60 \%$ of sludge. The coefficient of determination obtained was $89.57 \%$, which shows that $89.57 \%$ of the variations in the dry matter content of the root are explained by the variation in the sludge doses. The maximum availability of the phosphorus generally occurs in soils with a $\mathrm{pH}$ range of 6.0 to 7.0. The sludge liming promoted an elevation of the $\mathrm{pH}$ of the substrates and increase of the content of calcium and this may have favoured the formation of calcium phosphate that is insoluble and not usable by the plants. Several studies have shown that plants in $\mathrm{P}$ deficient soils tend to increase the root dry matter in detriment of the aerial part, since, in these conditions, the photosynthesis products are directed to the development of the root system, aiming to increase the $\mathrm{P}$ absorption area, seeking to compensate the low concentration of this element (CRUSCIOL et al., 2013).

The coefficients of determination (R2) obtained were $48.98 \%, 65.68 \%, 26.93 \%$ and $21.91 \%$ for the variables height, stalk diameter, foliar area and dry weight of the aerial part respectively. The coefficient of determination indicates in percentage how much the statistical model can explain the values observed. The higher the R2, the greater the response variation is explained by the regression obtained. In this study we found values considered low for R2, but as in the regression method by orthogonal polynomials the criterion of choice of the model was the linear regression of the highest significant degree, the adjusted models were maintained even with low R2 values. 
Figure 1 - Variables of growth of the coffee seedlings.
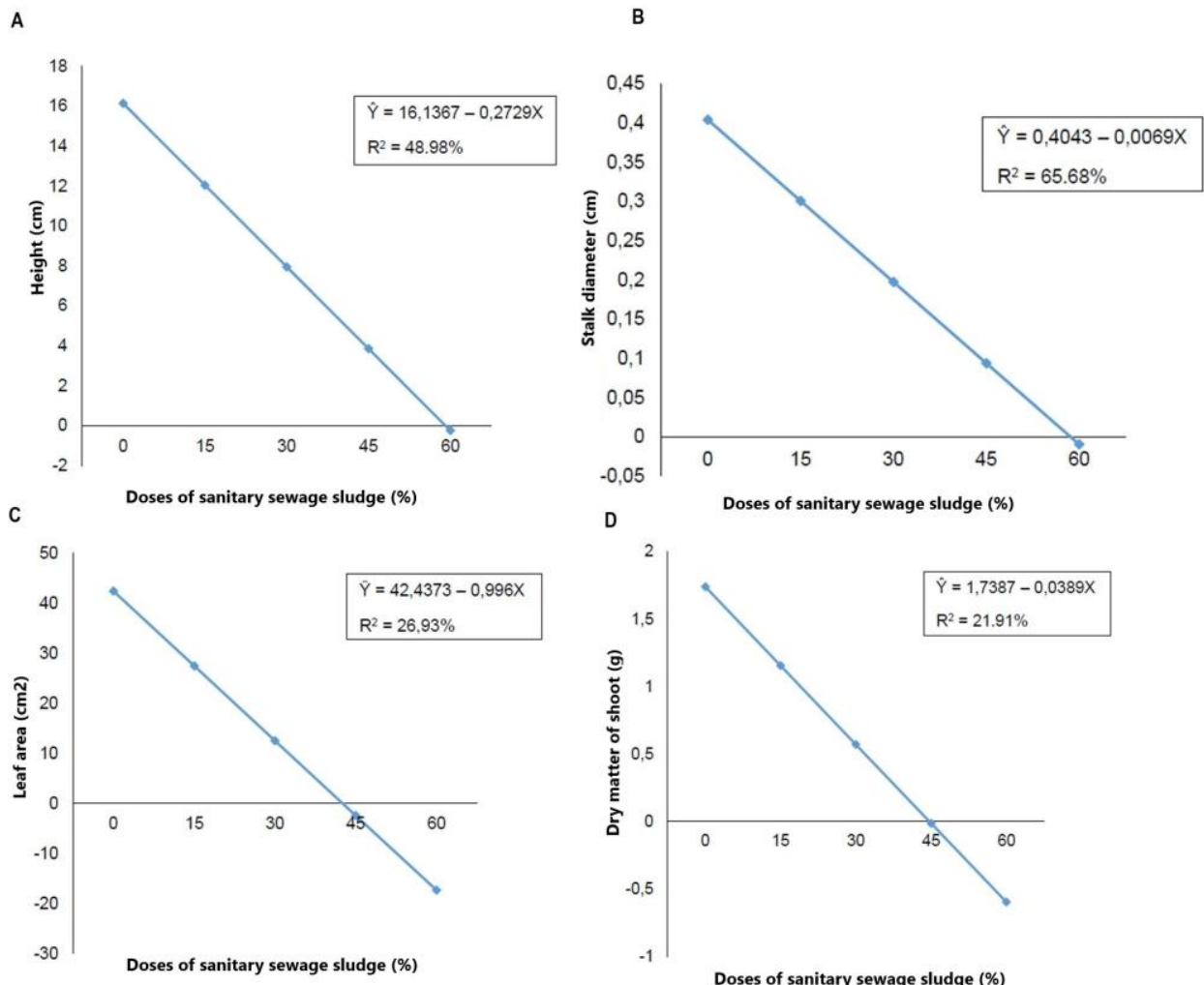

E

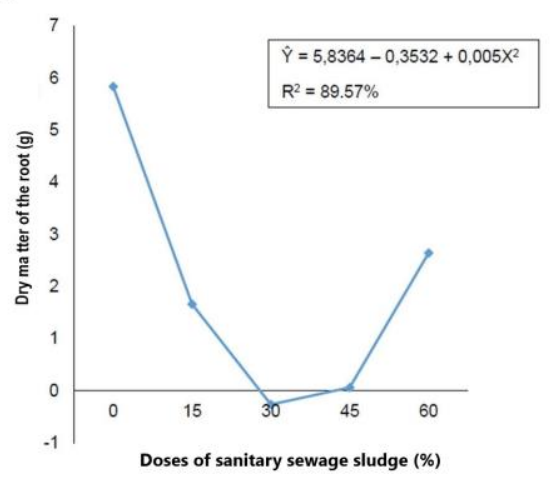

A: Height $(\mathrm{cm})$. B: Stalk diameter $(\mathrm{cm})$. C: Foliar area $\left(\mathrm{cm}^{2}\right)$. D: Dry weight of the aerial part $(\mathrm{g})$. E: Dry weight of the radicular $(\mathrm{g})$.

\subsection{Bioassay with A. cepa}

Table 2 shows the results for the mitotic index and frequency of aberrant cells. The negative control test presented $25.9 \%$ of cell in division and only $4 \%$ of altered cells. Colchicine $0.025 \%$ induced a significant reduction $(p<0.05)$ of the cell proliferation rate and statistically significant increase $(p<0.05)$ of the frequency of cells with aberrations, validating the test. Substrates S1 and S2 did not present cytogenotoxic activity for $A$. cepa. Substrate S3 was the only one that promoted a mitodepressive 
effect $(p<0.05)$ which characterizes this sample as cytotoxic (LEME, MARINMORALES 2009). The blockage of the cell cycle of the onion roots in the interphase is consistent with the $\mathrm{P}$ deficiency in this substrate and the low root growth of the coffee seedlings. The interphase is characterized by the synthesis of DNA, which has phosphorous as one of its components. Thus, the low availability of $P$ tends to inhibit the cell division and consequently delay the growth of the primary roots and the beginning of the differentiation process (TYBURSK et al., 2010). When an agent is highly cytotoxic, its genotoxic effect can be masked. Thus, the mitodepressive action of the substrate S3 resulted in the low rate of aberrant cells for this treatment.

The frequencies of genetic damages increased proportionally with the increase in the concentration of sewage sludge (except for S3 that presented cytotoxic activity), and substrates S4, S5 and LE were statistically significant $(p<0.05)($ Table 2$)$.

Table 2- Cytogenotoxicity of the substrates for $A$. cepa.

\begin{tabular}{cccc}
\hline Controls & No of dividing cells & Mitotic index (\%) & $\%$ of aberrante cells \\
\hline NC & 1294 & $25.9^{\mathrm{a}}( \pm 4.1)$ & $4^{\mathrm{a}}( \pm 0.6)$ \\
PC & 491 & $9.8^{\mathrm{b}}( \pm 2.1)$ & $7.34^{\mathrm{b}}( \pm 2.5)$ \\
\hline Substrates & & & \\
\hline S1 & 875 & $17.5^{\mathrm{a}}( \pm 5.5)$ & $1.5^{\mathrm{a}}( \pm 2.8)$ \\
S2 & 734 & $14.7^{\mathrm{a}}( \pm 3.6)$ & $2.1^{\mathrm{a}}( \pm 2.5)$ \\
S3 & 79 & $1.6^{\mathrm{b}}( \pm 4.5)$ & $1.3^{\mathrm{a}}( \pm 4.1)$ \\
S4 & 742 & $14.8^{\mathrm{a}}( \pm 5.2)$ & $8.2^{\mathrm{b}}( \pm 1.1)$ \\
S5 & 730 & $14.6^{\mathrm{a}}( \pm 3.2)$ & $12^{\mathrm{b}}( \pm 3.4)$ \\
LE & 961 & $19.2^{\mathrm{a}}( \pm 2.8)$ & $17.1^{\mathrm{b}}( \pm 4.7)$
\end{tabular}

S1: Substrate containing $15 \%$ bovine manure. S2: Substrate with $15 \%$ sanitized sewage sludge. S3: Substrate with $30 \%$ of sanitized sewage sludge. S4: Substrate containing $45 \%$ of sanitized sewage sludge. S5: Substrate with $60 \%$ sanitized sewage sludge. LE: $100 \%$ of sewage sludge. NC: Negative control - distilled water. PC: Positive control - colchicine $0.025 \%$. Equal letters do not differ significantly by the Kruskal-Wallis test $(p<0.05)$. ${ }^{*}$ Average of 5,000 cells analyzed .

The contribution of each alteration for the genotoxicity of the substrates S4, S5 and LE is showed in Figure 2. The most commonly observed alterations were micronucleus, polyploidy, binucleated cells, peripheral nucleus and lobulated nucleus and chromosome loss. 
Figure 2 - Distribution of the frequency of cell aberrations in the meristematic cells of $A$. cepa treated with substrates used in the growth of coffee seedlings.

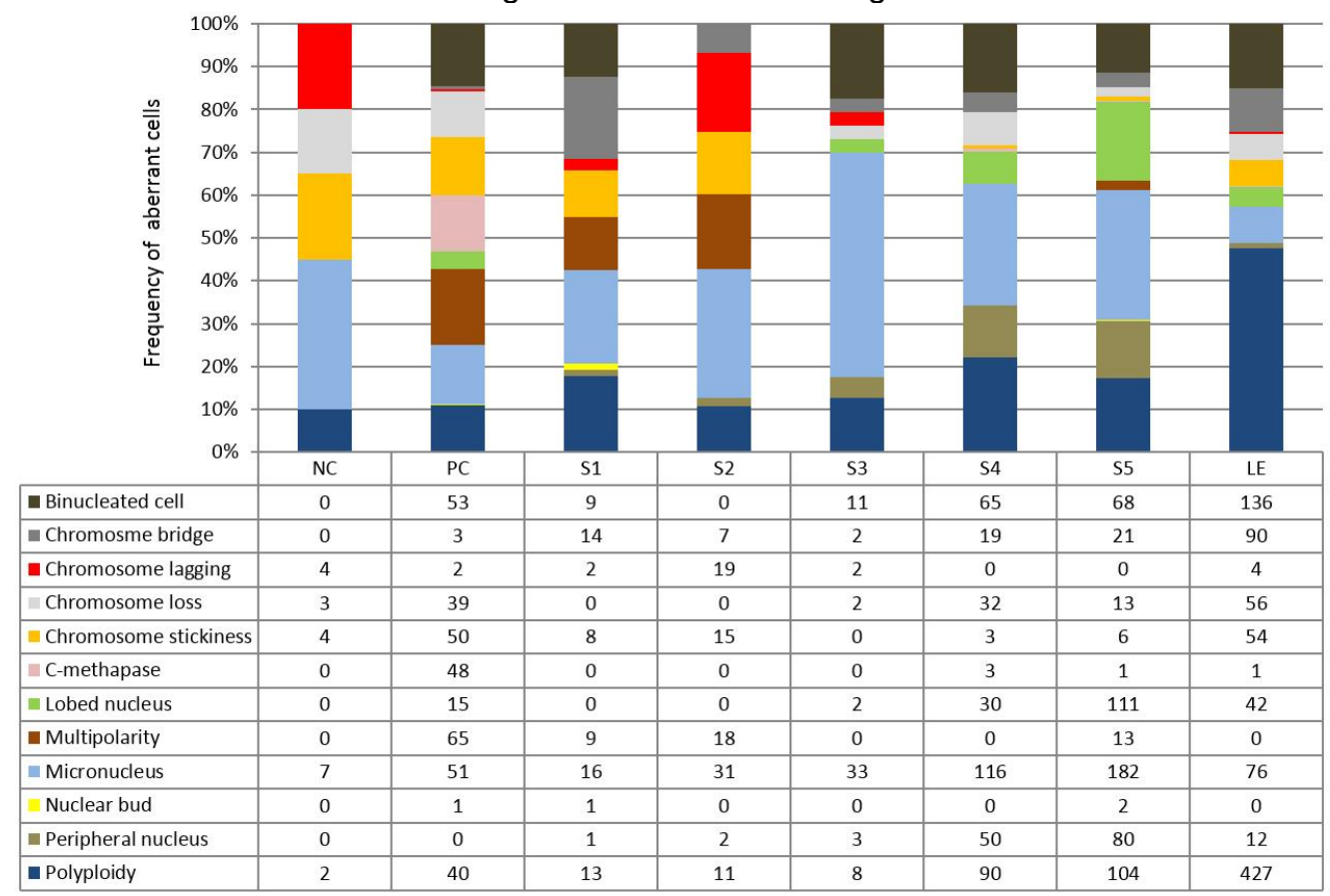

S1: Substrate containing 15\% bovine manure. S2: Substrate with 15\% sanitized sewage sludge. S3: Substrate with $30 \%$ sanitized sewage sludge. S4: Substrate containing $45 \%$ sanitized sewage sludge. S5: Substrate with 60\% sanitized sewage sludge. LE: $100 \%$ sewage sludge. NC: Negative control distilled water. PC: Positive control - colchicine $0.025 \%$.

The analysis of the alterations observed indicated that the samples with the highest concentration of sewage sludge predominantly interacted with the cellular apparatus that regulates the integrity of the genome, such as the mitotic spindle: polyploidy, multipolar cells and chromosomal loss (KIRSCH-VOLDERS et al., 2002; FERNANDES et al., 2009). Micronuclei result from damages (fragments or chromosome losses) in the parental cells, which are transmitted to the daughter cells (RIBEIRO, 2003). Possibly, the micronuclei observed in this study originated from aneugenic mechanisms, since chromosomal breaks were not observed. Lobed nuclei would be derived from chromosome bridges with subsequent absence of cytoplasmic division. The induction of peripheral nuclei and chromosome adherence are alterations characteristic of cells in cell death process (FISKESJÖ, 1985), indicating the toxic action of the sewage sludge. The results of this study corroborate other studies that have shown that sewage sludge of different origins (domestic and industrial) can promote chromosome aberrations in plants (AMIN et al., 2009; MAZZEO et al., 2015). 
Despite the direct effects of the sludge on the coffee seedlings and in the onion root cells, priority environmental pollutants related to the deleterious effects of the sewage sludge studied could not be detected, since the levels of the metals and organic pollutants did not exceed the maximum levels established by the CONAMA Resolution ํo 375 (BRASIL, 2006). Since the sewage sludge is a complex mixture, and it is practically economically impossible to identify and quantify all the chemical elements present, biological tests are of paramount importance for a more realistic analysis of the quality of the residue. In the present study, it was clear that the treatment of the sewage that arrives at the Treatment Station removes cytogenotoxins of the effluents, but does not inactivate them. Therefore, these agents end up being captured in the sewage sludge and probably, act synergistically. The effects of these compounds have been readily detected by genetic toxicity tests performed with higher plants (MAZZEO et al., 2015; MARTINS et al., 2016b) and other test systems such as mammalian cells (BONOMO et al., 2016).

\section{CONCLUSION}

Coffee seedlings from substrate with the lowest proportion of sludge (15\%) obtained the best growth performance. This substrate also did not present cytogenotoxic activity, being equivalent to the bovine manure. In addition to the influence of the $\mathrm{pH}$ and the nutritional deficiency, we infer that the increasing concentrations of sewage sludge in the substrates may be the main responsible for the low growth of the seedlings, due to the presence of pollutants in the residue, resulting in toxicity. This result is supported by the data obtained in the bioassay with $A$. cepa, in which the frequency of aberrant cells increased as a function of the addition of sludge. As the level of each pollutant did not exceed the maximum limits allowed by the Brazilian legislation, the toxic action of the sludge can be attributed to the synergic effect of all pollutants.

\section{ACKNOWLEDGEMENT}

We thank the Foundation for Research and Innovation of Espírito Santo (FAPES) for the financial support (process no 67707122), Sanitation Company of Espírito Santo. Glaucia Cunha thankful Viviane Tavares de Paula for the technical support. 


\section{REFERENCES}

ABNT- ASSOCIAÇÃO BRASILEIRA DE NORMAS TÉCNICAS. NBR 10007:2004 - Amostragem de resíduos sólidos (Sampling of solid waste). ABNT, Rio de Janeiro, 21p.

ABNT - Associação Brasileira de Normas Técnicas. NBR ISO/IEC 17025:2017 - Requisitos gerais para a competência de laboratórios de ensaio e calibração. ABNT, Rio de Janeiro, $32 \mathrm{p}$.

ALVES, A.R.; BACKES, C.; SANTOS, A.J.M.; RIBON, A.A.; BESSA, S.V. Produção de mudas de cafeeiro com substratos contendo composto de lodo de esgoto. Enciclopédia Biosfera, v. 13, n. 24, p. 837-846, 2016.

AMIN, A.W.; SHERIF, F.K.; EL-ATAR, E.; EZ-ELDIN, H. Residual effect of sewage sludge on soil and several yield parameters of Zea mays. Research Journal of Environmental Toxicology, v. 3, p. 86-93, 2009.

Banzatto, D.A.; Kronka, S.N. Experimentação agrícola. Jaboticabal: FUNEP, 237p., 2006.

BERGO, C. L.; SÁ, C.P.; SALES, F. Produção de mudas de cafeeiro por sementes e estacas. Circular Técnica n44. Empresa Brasileira de Pesquisa Agropecuária, 2002.

BONOMO, M.M.; MOROZESK, M.; DUARTE, I.D.; ROCHA, L.D.; FERNANDES, M.N.; MATSUMOTO, S.T. Sewage sludge hazardous assessment: chemical evaluation and cytological effects in CHO-K1cells. Environmental Science and Pollution Research, v. 23, p. 11069-11075, 2016.

BRASIL. MINISTÉRIO DO MEIO AMBIENTE. CONAMA - Conselho Nacional do Meio Ambiente. Resolução no 375, de 29 de agosto de 2006. Define critérios e procedimentos, para o uso agrícola de lodos de esgoto gerados em estações de tratamento de esgoto sanitário e seus produtos derivados. Diário Oficial da República Federativa do Brasil , Brasília, 30 ago. 2006. Disponível em: http://www.mma.gov.br/port/conama/res/res06/res37506.pdf. Acessed in: January 25, 2016.

CALDEIRA, M.V.W.; DELARMELINA, W.M.; PERONI, L.; GONÇALVES, E.O.; SILVA, A.G. Lodo de esgoto e vermiculita na produção de mudas de eucalipto. Pesquisa Agropecuária Tropical, v. 43, p. 155-163, 2013.

COSTA, A. N.; RODRIGUES, C.; TELES C.R.; KRHOLING, B. Reciclagem agrícola do lodo de lagoas de estabilização. In: GONÇALVES, R.F. (Org.), Gerenciamento do lodo de lagoas de estabilização não mecanizadas. PROSAB - Programa de Pesquisa em Saneamento Básico. FINEP - Financiadora de Inovação e Pesquisa, 1999. p. 60-68.

CRUSCIOL, C.A.C.; NASCENTE, A.S.; MAUAD, M.; SILVA, A.C.L. Desenvolvimento radicular e aéreo, nutrição e eficiência de absorção de macronutrientes e zinco por cultivares de arroz de terras altas afetadas pela adubação fosfatada. Semina: Ciências Agrárias, v. 34, p. 2061-2076, 2013.

CRUZ, C.D. Programa Genes estatística experimental e matrizes. Viçosa: UFV, 285p., 2006.

CUNHA, A.M.; CUNHA, G.M.; SARMENTO, R.A.; CUNHA, G.M.; AMARAL, J.F.T. Efeito de diferentes substratos sobre o desenvolvimento de mudas de Acacia sp. Revista Árvore, 30, 207-214, 2006. 
EMBRAPA (Empresa Brasileira de Pesquisa Agropecuária). Centro Nacional de Pesquisa de Solos. Manual de métodos de análise de solo. Rio de Janeiro, Brasil, 2. ed. rev. atual., 212 p., 1997.

EMBRAPA (Empresa Brasileira de Pesquisa Agropecuária). Embrapa Agrobiologia. Sistemas de produção: cultivo do café orgânico. Seropédica, Brasil, 95 p., 2004.

FERNANDES, T.C.C.; MAZZEO, D.E.C.; MARIN-MORALES, M.A. Origin of nuclear and chromosomal alterations derived from the action of an aneugenic agent - trifluralin herbicide. Ecotoxicology and Environmental Safety, v. 72, p. 1680-1686, 2009.

FISKEJÖ, G. The Allium test as a standard in environmental monitoring. Hereditas, v. $102 \mathrm{n}$. 1, p. 99-112, 1985.

INCAPER - Instituto Capixaba de Pesquisa, Assistência Técnica e Extensão Rural. Incaper em Revista - Café sustentável. v.1, $n^{0} 1$, jan./dez. 2010. Available in: www.incaper.es.gov.br. Acessed in: Novembro 08, 2017.

KIRSCH-VOLDERS, M.; VANHAUWAERT, A.; DE BOECK, M.; DECORDIER, I. Importance of detecting numerical versus structural chromosome aberrations. Mutation Research, $v$. 504, p. 137-148, 2002.

LEME, D.M.; MARIN-MORALES, M.A. Allium cepa test in environmental monitoring: a review on its application. Mutation Research, v. 682, p. 71-81, 2009.

LIMA, M.F.; MATTOS, C.N.; VIEIRA, P.L.C.; ALMEIDA, L.F. Geração de lodo de esgoto e seu potencial como fonte de matéria orgânica para a agricultura. In: COSTA, L.F., COSTA,

A.F.S. (Eds.), Manual de uso agrícola e disposição do lodo de esgoto para o estado do Espírito Santo. Vitória: Incaper, 2011. p. 11-18.

LOPES, N.F.; MAESTRI, M. Análise de crescimento e conversão da energia solar em populações de milho (Zea mays L.) em Viçosa, Minas Gerais. Revista Ceres, v. 20, p. 189-192, 1973.

MARQUES, M.A.M.; GOMES, I.H.; BERNADINO, U.B. Estimativa da produção de lodo nas estações de tratamento de esgoto Mulembá e Vale Encantado da CESAN (ES). Revista Científica FAESA, v. 11, 41-50, 2015.

MARTINS, M.N.C.; SOUZA, V.V.; SOUZA, T.S. Genotoxic and mutagenic effects of sewage sludge on higher plants. Ecotoxicology and Environmental Safety, v. 124, p. 489-496, 2016a.

MARTINS, M.N.C.; SOUZA, V.V.; SOUZA, T.S. Cytotoxic, genotoxic and mutagenic effects of sewage sludge on Allium cepa. Chemosphere, v. 148, p. 481-486, $2016 \mathrm{~b}$.

MAZZEO, D.E.C.; FERNANDES, T.C.C.; LEVY, C.E.; FONTANETTI, C.S.; MARINMORALES, M.A. Monitoring the natural attenuation of a sewage sludge toxicity using the Allium cepa test. Ecological Indicators, v. 56, p. 60-69, 2015.

RANK, J.; NIELSEN, M.H. Evaluation of the Allium anaphase-telophase test in relation to genotoxicity screening of industrial wastewater. Mutation Research, v. 312, p. 17-24, 1994.

RIBEIRO, L.R. Teste do micronúcleo em medula óssea de roedores in vivo. In: L.R.

RIBEIRO, D.M.F. SALVADORI, \& E.K. MARQUES (Eds.), Mutagênese Ambiental, Editora da Ulbra, 201-219, 2003. 
SILVA, L.T. Qualidade de mudas de café (Coffea arabica) produzidas em substrato contendo biossólido. Monografia. - Universidade Federal de Uberlândia. 36p., 2015

SOUZA, D.M.S.C.; AMORIM, Y.F.; NOVAES, A.B.; SANTANA, T.M.; ABREU, G.M.; AGUIAR JUNIOR, A.L. Produção de mudas de café arábica em diferentes combinações de substratos e doses de superfosfato simples. Revista Espacios, v. 38, p. 2-10, 2017.

SCHUMACHER, M.V.; CECONI, D.E.; SANTANA, C.A. Influência de diferentes doses de fósforo no crescimento de plantas de Peltophorum dubium (Sprengel) Taubert. Boletim de Pesquisa Florestal, v. 47, p. 99-114, 2003.

TATAGIBA, S.D.; PEZZOPANE, J.E.M.; REIS, E.F. Crescimento vegetativo de mudas de café arábica (Coffea Arabica L.) submetidas a diferentes níveis de sombreamento. Coffee Science, v. 5, p. 251-261, 2010.

TYBURSKI, J.; DUNAJSKA, K.; TRETYN, A. A role for redox factors in shaping root architecture under phosphorus deficiency. Plant Signaling \& Behavior, v. 5, n. 1, p. 64-66, 2010. 